\title{
LA LEUCOPLASIA VIRAL LINGUAL DEL SIDA
}

\author{
GERZAIN RODRIGUEZ TORO, M.D.* ${ }^{*}$ ORLANDO RICAURTE GUERRERO, M.D.**
}

La leucoplasia pilosa oral de una biopsia en un hombre de 27 años de edad, marcador de infección con el virus de HIV e indicador de progresión en pocos meses al SIDA, muestra un cuadro histológico típico caracterizado por hipérplasia epitelial irregular, cambio coilocítico e inclusiones intranucleares en la mitad superior del epitelio. La ultraestructura de estas inclusiones corresponde a cápsides y nucleocapsidios de virus del Grupo Herpes. Los estudios inmunoenzimáticos para Papilomavirus, Herpes I y II fueron negativos. Por exclusión, hay evidencia razonable para concluir que las partículas demostradas son de virus de Epstein-Barr. Sólo se debe aceptar como leucoplasia pilosa oral aquella lesión en la que se demuestre, por cualquier método, la presencia de virus de Epstein-Barr. El estudio histológico usual de la entidad es característico y permite hacer un diagnóstico confiable.

\section{INTRODUCCION}

La leucoplasia pilosa oral (LPO) o leucoplasia viral lingual es una placa blanquecina y corrugada, adherente, que se presenta en los márgenes o en la cara ventral de la lengua en pacientes infectados con el virus del SIDA (HIV) (Fig.1). Descrita y caracterizada entre 1981 y 1984 (1), se sabe hoy que es un marcador de infección con el virus HIV, que puede ser la primera manifestación del SIDA y que su presencia se asocia con una rápida progresión hacia el síndrome franco de inmunodeficiencia: $48 \%$ lo presentan a los 16 meses de identificada la leucoplasia y $83 \%$ a los 31 meses (2). Su causa es la presencia intranuclear en el epitelio lingual del virus de Epstein-Barr $(1,3)$. Puede haber candidiasis asociada y es posible la presencia simultánea de Papilomavirus (1).

\section{Caso clínico:}

Hombre de 27 años de edad, recluido en una penitenciaría de Bogotá. Consultó al Servicio de Odontología de la Universidad Nacional en el Hospital San
Juan de Dios (Dr. Germán Hernández), por presentar en la región lateral derecha de la lengua una placa blanquecina, rugosa, de bordes mal definidos. Presentaba además diarrea crónica, pérdida de peso, candidiasis orofaríngea y disturbios mentales. Una ELISA

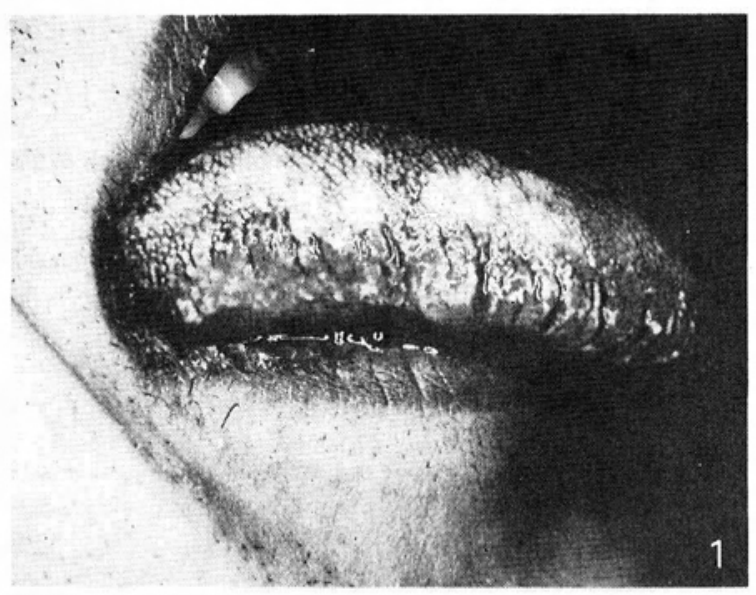

Fig. 1. Placa blanquecina, adherente del borde de la lengua.

\footnotetext{
* Jefe del Grupo de Patología del Instituto Nacional de Salud. Profesor Titular de Cátedra, de los Departamentos de Morfología y Patología de la Facultad de Medicina de la Universidad Nacional de Colombia - Bogotá.

** Patólogo del Grupo de Patología, Instituto Nacional de Salud Bogotá - Colombia.
} 
reciente para HIV fue negativa. Se tomó biopsia de la lesión lingual que se envió al INS para estudio de microscopia de luz y electrónica.

\section{MATERAL Y METODOS}

La biopsia se procesó así:

a. Para microscopía de luz con inclusión en parafina y cortes teñidos con HE y PAS.

b. Para técnicas inmunoenzimáticas en este mismo material, para demostrar antígeno de Papilomavirus, y Herpes simplex tipo I y II, usando anticuerpos polivalentes. Como controles se usaron casos de infecciones por estos virus que ya habían dado resultados positivos en la misma prueba y por microscopía electrónica.

c. Para microscopía electrónica con doble fijación en glutaraldehído-ácido ósmico e inclusión en Spurr.

\section{RESULTADOS}

a. Microscopia de luz: se demuestra un cuadro caracterizado por (Figs. 2-7):

- Hiperplasia epitelial con hiperqueratosis.
- Vacuolización citoplasmática discreta, focal de la parte media y superior del epitelio.

- Inclusiones intranucleares, en la mitad superior del epitelio, basófilas, homogéneas, que llenan todo el núcleo o rechazan y marginan la cromatina hacia la membrana nuclear, de la cual pueden estar separadas por un pequeño halo (Cowdry Tipo A) (Figs. 3-5).

- Ausencia de infiltrados inflamatorios.

- Con la coloración de PAS se demostraron esporos y pseudomicelios de Candida sp en las capas superficiales del epitelio (Fig. 7).

b. Inmunoperoxidasa: todas las pruebas dieron resultados negativos, en presencia de los controles adecuados.

c. Microscopía electrónica: se realizó para demostrar la naturaleza de las inclusiones que correspondieron a acúmulos de material denso, granular dentro del cual se identifican numerosas cápsides y núcleo-cápsides con morfología de virus del Grupo Herpes (Fig. 8). La obtención de la envoltura viral a partir de la membrana nuclear no fue aparente, como sí lo es en infecciones por virus Herpes I y II, razón por la cual la membrana del núcleo permanece nítida. Se vieron ocasionales

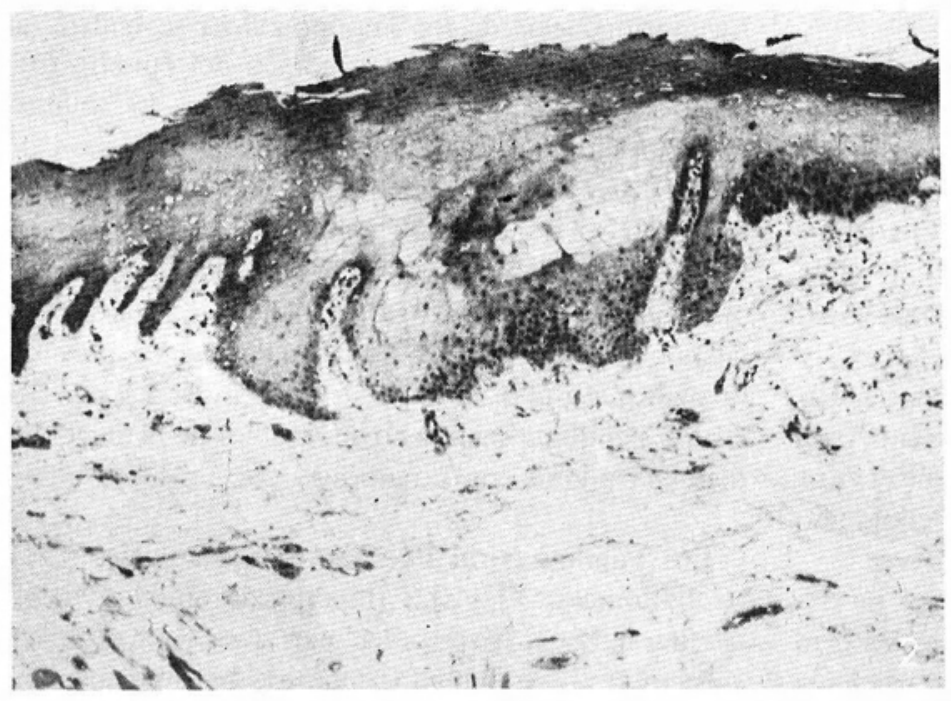

Figura.. 2. L.P.O. Hiperplasia epitelial irregular con cambio vacuolar coilocítico en el centro de la imagen. HE. $63 \mathrm{X}$. 


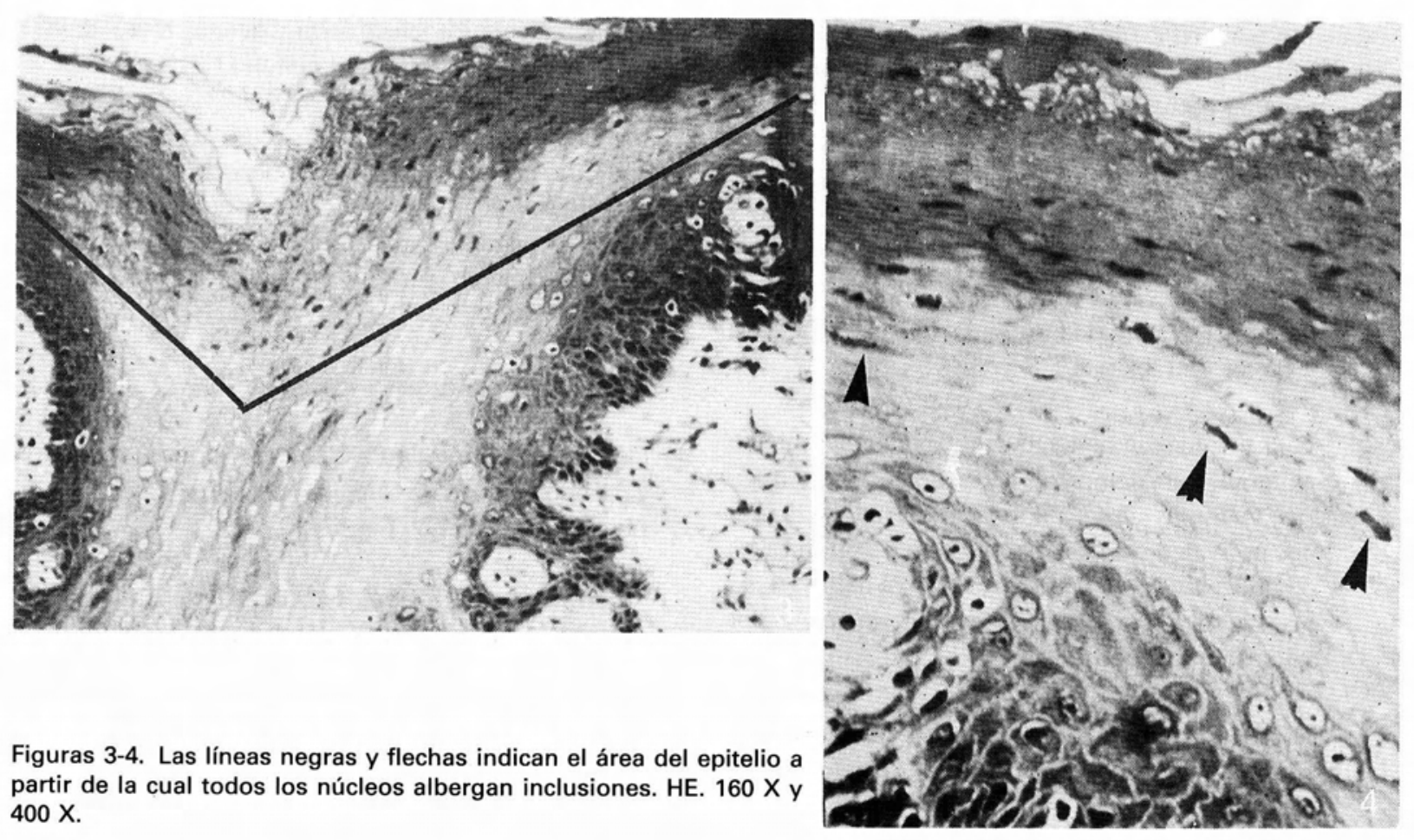

partículas en el citoplasma claro y filamentoso de estas células epiteliales y fue muy aparente la presencia de viriones en el espacio intercelular (Fig. 9).

La búsqueda de Papilomavirus dió resultados negativos.

\section{COMENTARIOS}

Los hallazgos descritos, clínicos y microscópicos corresponden a la leucoplasia vellosa oral, una de las varias entidades responsables de lesiones blancas de la boca (4). La confirmación definitiva está dada por la demostración ultraestructural de partículas de virus del Grupo Herpes en las inclusiones intranucleares. $\mathrm{La}$ inmunoperoxidasa negativa para virus Herpes I y II y el hecho de que el virus de la inclusión citomegálica no produzca un cuadro como el descrito, son evidencia indirecta importante para sugerir que el virus demostrado es el de Epstein-Barr, agente etiológico de la afección (1-2).

Las infecciones por virus Herpes I - II se asocian con necrosis celular extensa, formación de sincicios y multinucleación, lo que contrasta con el aspecto hiperplásico leve y no inflamatorio de la lesión que describimos.

Algunos Papilomavirus originan voluminosas inclusiones intranucleares (5) y además son los virus reconocidos como productores del cambio vacuolar citoplasmático o coilocítico en los epitelios que afecta. La morfogénesis de los Papilomavirus se realiza en las capas altas, granulosa y córnea del epitelio (5), como en las inclusiones aquí descritas. La imagen ultraestructural descarta que las inclusiones sean de estos virus. Si bien hay estudios inmunoenzimáticos que demuestran la presencia de antígeno de Papilomavirus en la leucoplasia pilosa lingual (1), su demostración ultraestructural no es satisfactoria, sobre todo cuando su morfología es tan característica. La posibilidad de que ambos virus, el de Epstein-Barr y uno del Grupo Papiloma sean los responsables de la afección, merece estudios confirmatorios.

Los Papilomavirus tipo 2 (verruga vulgar), 6, 11 (Condilomas), 13 y 32, (hiperplasia epitelial focal) afectan la boca, pero las lesiones que originan tienen aspecto sésil, pediculado, aplanado, no blanquecino, 

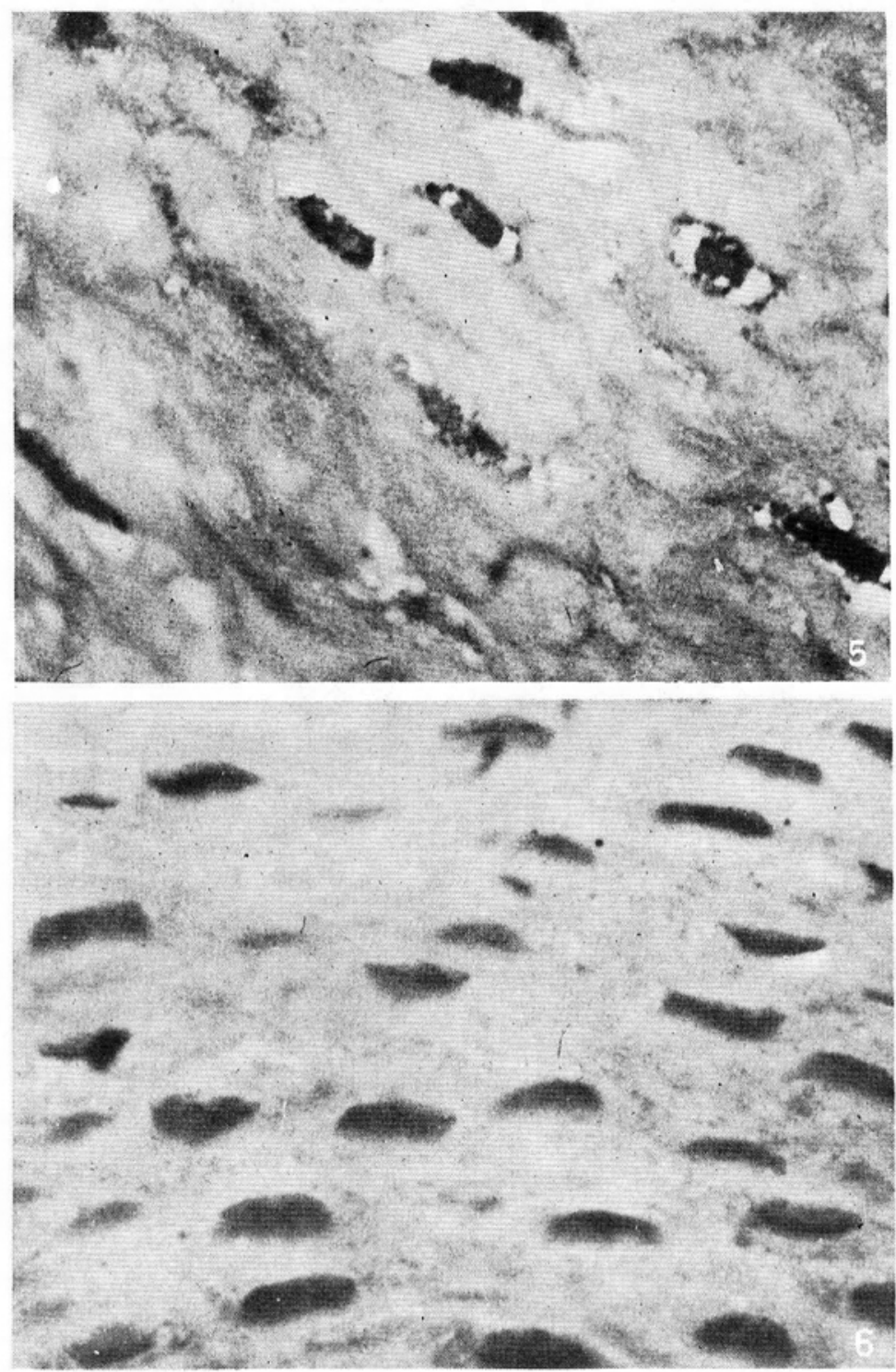

Figs. 5 y 6 . Detalle de las inclusiones intranucleares (Fig.5). La figura (6) corresponde a epitelio de una biopsia lingual normal en un área equivalente a la ilustrada en la Fig. 5, fotografiada con el mismo aumento. Compárense las dos imágenes. HE 1000 $\mathrm{X}$.
Fig. 7. Esporos y pseudomicelios de Cándida sp en el tercio externo del epitelio. PAS $400 \mathrm{X}$.

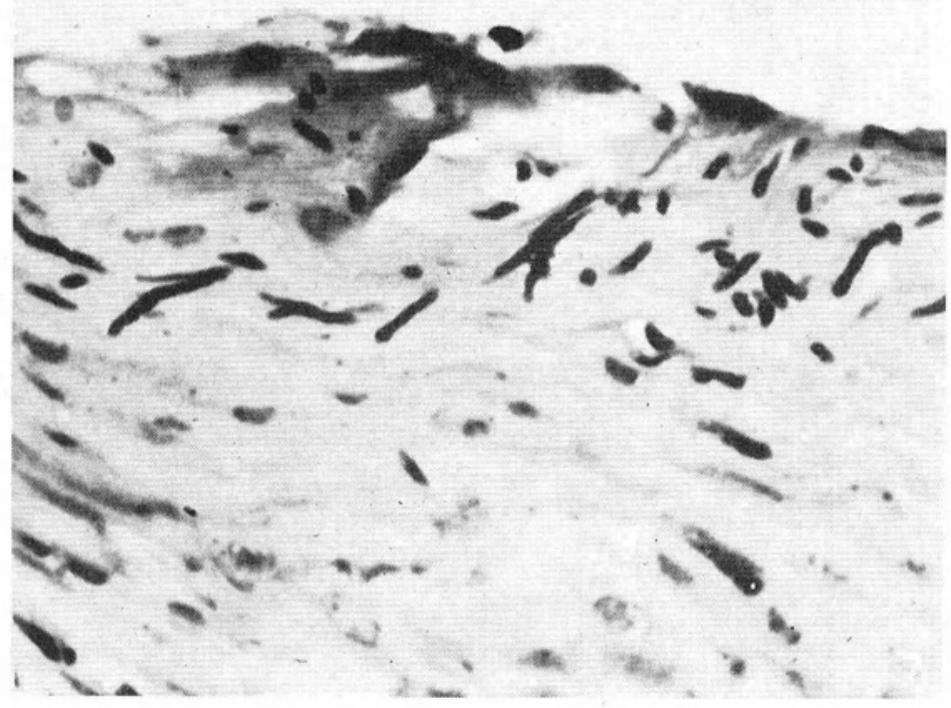




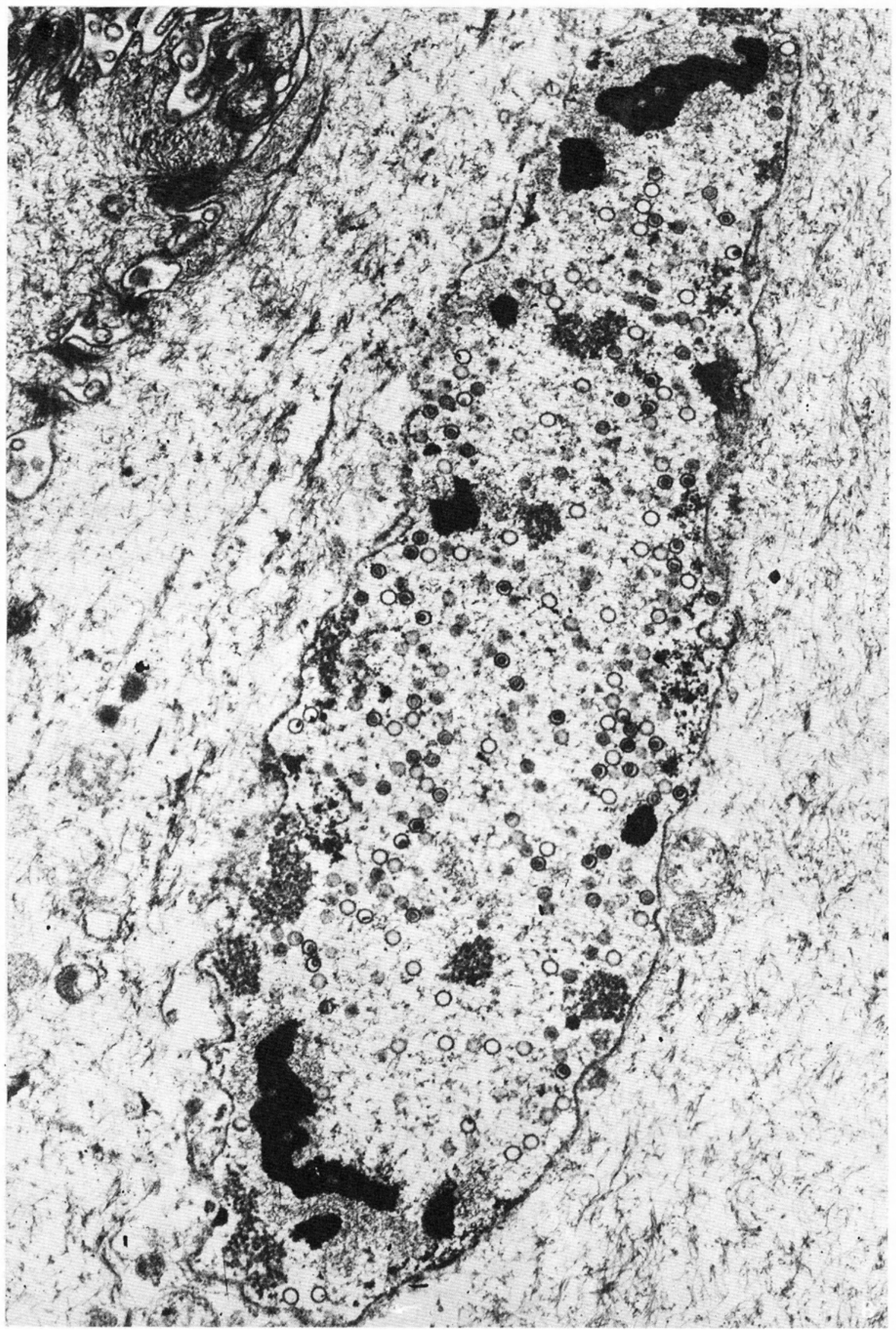

Fig. 8. La inclusión corresponde a material granular, cápsides y nucleocápsides de virus del Grupo Herpes. 25.000 X. 


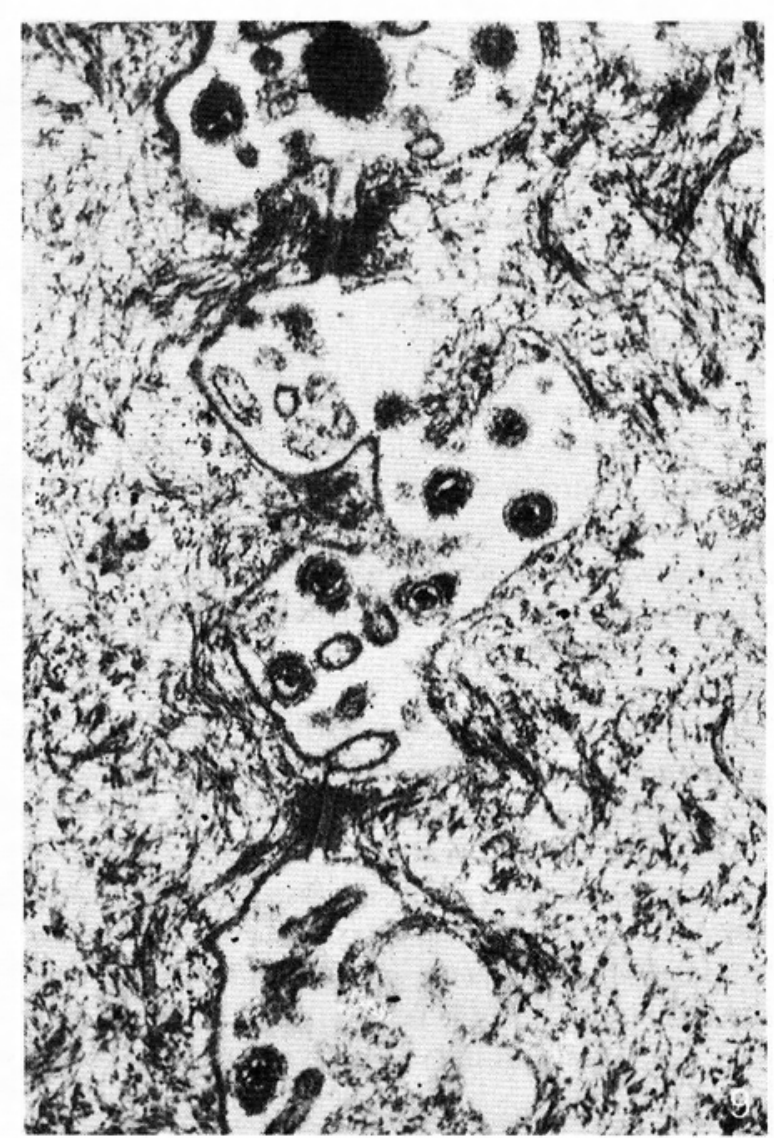

Fig. 9. Viriones herpéticos en el espacio intercelular; son bien aparentes el nucleoide denso, la cápside y la envoltura viral. $36.000 \mathrm{X}$.

y su imagen de microcopía de luz no muestra inclusiones porque la cantidad de virus presente es escasa, como para ser detectada en las coloraciones usuales de microscopía de luz.

Es muy importante tener en cuenta que la entidad puede diagnosticarse con la sola HE, que demuestra las inclusiones intranucleares en la mitad superior del epitelio lingual. Ningún Papilomavirus conocido origina inclusiones semejantes en este epitelio y los herpes I y II pueden descartarse por la ausencia de inflamación, de sincicios y de necrosis. Si bien las técnicas inmunoenzimáticas, la hibridización del ADN, la microscopía electrónica y los cultivos para virus son condiciones ideales en el estudio de estos pacientes, el examen histológico usual permite hacer el diagnóstico de la LPO. Es posible que la naturaleza de la entidad llegue a ser definida por la demostración de virus de Epstein-Barr en la lesión, por cualquiera de los métodos mencionados, incluyendo el histológico, con las características descritas. Este es un hecho esencial para definir su valor pronóstico, pues hay muchas entidades que producen lesiones blancas en la boca (3), que podrían confundirse con la LPO.

La presencia de Candida sp en este paciente refleja la adición de otro germen oportunista en la lesión, como expresión de la inmunosupresión; la historia clínica del paciente, los hallazgos del examen físico y la microscopía descrita confirman que el paciente padece de SIDA, así el examen inicial de ELISA para HIV haya sido negativo.

\section{AGRADECIMIENTOS}

A la señorita Leonor Cipagauta Galvis por la asistencia técnica, al señor Enrique Rivera por el trabajo fotográfico, al doctor Mariano López por suministrarnos la fotografía clínica, al doctor Germán Hernández por remitirnos la biopsia para estudio ultraestructural, a la señora Matilde Guzmán de Mojica por mecanografiar el manuscrito.

\section{BIBLIOGRAFIA}

1. Greenspan S John, et al. Replication of Epstein-Barr virus within the epithelial cells of oral "Hairy leukoplakia", an AIDSAssociated lesion. N Engl J Med. 1985; 313: 1564-71.

2. Greenspan D, et al. Relation of oral hairy leukoplakia to infection with the human immunodeficiency virus and the risk of developing AIDS. J Infect Dis. 1987; 155: 475-81.

3. Fowler B Craig, et al. Intranuclear inclusion correlate with the ultrastructural detection of Herpes - Type virions in oral Hairy leukoplakia. Am J Surg Pathol. 1989; 13 (2): 114-119.

4. Randle H. White lesiones of the mouth. Dermatologic Clinics. 1987; 5 (4): 641-650.

5. Rodríguez G. Microscopía Electrónica de la infección viral. Instituto Nacional de Salud. Bogotá, 1983. 